
segregating sweet corn populations. Horticultura Brasileira 38: 71-77. DOI - http://dx.doi.org/10.1590/S0102-053620200111

\title{
Selection indexes for agronomic and chemical traits in segregating sweet corn populations
}

\author{
Marina F e Silva ${ }^{1 * \mathbb{D}}$; Gabriel M Maciel ${ }^{2} \mathbb{D}$; Rafael R Finzi ${ }^{1} \mathbb{D}$; Joicy Vitoria M Peixoto ${ }^{1} \mathbb{D}$; Wender S \\ Rezende $^{3} \mathbb{D}$; Renata Castoldi ${ }^{2} \mathbb{D}$
}

${ }^{1}$ Universidade Federal de Uberlândia (UFU), Uberlândia-MG, Brasil; marinafreitas.agro@hotmail.com (*author for correspondence); rafaelfinzi@hotmail.com; joicyvmpeixoto@yahoo.com; ${ }^{2}$ Universidade Federal de Uberlândia (UFU), Monte Carmelo-MG, Brasil; gabrielmaciel@ufu.br; rcastoldi@ufu.br; ${ }^{3}$ Universidade Federal de Viçosa (UFV), Viçosa-MG, Brasil; wendersrezende@gmail.com

\begin{abstract}
In the sweet corn breeding, the selection of superior genotypes should consider many traits simultaneously. The best strategy to select traits simultaneously is through selection indexes. This study aimed to compare the efficiency of different selection indexes based on characteristics with direct effect on grain yield in segregating sweet corn populations. Eighteen traits were evaluated in eight sweet corn genotypes on generation F3. Data were submitted to analyses of variance and path coefficient analyses. We compared the direct and indirect selection and the following indexes: base, classical, desired gains and genotype-ideotype distance. According to path coefficient analyses, the traits which showed a direct effect about grain yield (GY) were stand, number of ears, ear diameter, number of grains per row and industrial yield, which composed the indexes. The base index provided the greatest total genetic gain, desired gains on all traits, uniform distribution of the gains and considerable gains on GY.
\end{abstract}

Keywords: Zea mays subsp. sacharatta, plant breeding, selection gain, simultaneous selection of characteristic.

\section{RESUMO}

Índices de seleção para caracteres agronômicos e químicos em população segregante de milho-doce

No melhoramento genético de milho-doce, o processo de seleção de genótipos superiores deve considerar simultaneamente diversos caracteres. A melhor estratégia para a seleção simultânea de caracteres é o uso de índice de seleção. Visto isso, o objetivo do trabalho foi comparar a eficiência desses diferentes índices de seleção com base nas características que possuem efeito direto na produtividade de grãos em populações segregantes de milho doce. Foram avaliados 18 caracteres em oito genótipos de milho-doce na geração F3. Os dados foram submetidos à análise de variância e análise de trilha. Foi comparada a seleção direta e indireta e os seguintes índices: base, clássico, seleção de ganhos desejados e distância genótipo-ideótipo. De acordo com a análise de trilha, os caracteres que apresentam efeito direto com a produção de grãos (PG) foram estande, número de espigas, diâmetro de espiga, número de grãos por fileira e rendimento industrial, os quais compuseram os índices. $\mathrm{O}$ índice base proporcionou o maior ganho de seleção total, ganhos desejáveis positivos em todos caracteres, distribuição uniforme dos ganhos entre as características avaliadas e ganho satisfatório em PG.

Palavras-chave: Zea mays subsp. sacharatta, melhoramento de planta, ganho de seleção, seleção simultânea de caracteres.

\section{Received on October 21, 2019; accepted on February 26, 2020}

$\mathrm{S}$ weet corn (Zea mays subsp. sacharatta) is a special type of corn that has a greater concentration of sugars in the grains in relation to common corn. This characteristic is ruled by one or more genes of recessive allele, such as genes shrunken and sugary, which inhibit the conversion of sugars into starch in the endosperm, giving great palatability (Dodson-Swenson \& Tracy, 2015). In addition, sweet corn is intended solely for human consumption, mainly after industrial processing (Pereira Filho \& Teixeira, 2016).
The demand for sweet corn has increased in Brazil, but the number of cultivars adapted to the regions of cultivation is still low, with only 77 registered cultivars (MAPA, 2019). Therefore, it is necessary to intensify the development of new materials, in addition to research related to the improvement of this crop to support future breeding programs. A sweet corn cultivar, besides being productive, must have good organoleptic characteristics and attend the particularities of the industry, such as appropriated ear length and diameter for processing (Perfeito et al., 2017). Therefore, in the genetic improvement of sweet corn, the process of selection of superior genotypes should consider several types of characteristics simultaneously, such as agronomic, chemical and organoleptic properties.

In this context, the selection based only on one trait (direct selection), such as productivity, is not considered the most appropriated strategy, since there is no guarantee of genetic gains in other important traits, which may, or may not be correlated to the productivity (Jahufer 
\& Casler, 2015). To select superior sweet corn genotypes, various characteristics (simultaneous selection of traits) can be evaluated using selection indexes.

The selection indexes are an analysis of simultaneously established selection by a linear combination of traits to maximize the gains from the selection in all the attributes considered (Cruz et al., 2012). There are several reports of the efficiency of the use of selection indexes in relation to the direct selection in crops such as baby corn and green corn (DoVale et al., 2011), soybean (Andrade et al., 2016), carrot (Carvalho et al., 2017) and passion fruit (Neves et al., 2011).

Different methodologies of selection indexes have been described such as Smith-Hazel (Smith, 1936; Hazel, 1943), Pesek-Baker (Pesek \& Baker, 1969) and genotype-ideotype distance (Cruz, 2006). The comparison between the indexes can be performed by means of genetic gains predicted by each index or by coincidence in the selection of superior genotypes (Leite et al., 2018). There are several studies that have compared the efficiency between the selection indexes (Andrade et al., 2016; Bizari et al., 2017; Missanjo \& Matsumura, 2017). However, there are still few studies with this approach in the sweet corn.

Thus, the objective of this study was to compare the efficiency of different selection indexes based on characteristics with direct effect on grain yield in segregating sweet corn populations.

\section{MATERIAL AND METHODS}

The experiment was conducted under irrigation by aspersion, in the period from March $3^{\text {rd }}$ to June $20^{\text {th }}$ (2018) at the Experimental Station of Vegetables of the Universidade Federal de Uberlândia (UFU), Campus Monte Carmelo, Brazil $\left(18^{\circ} 43^{\prime} \mathrm{S}, 47^{\circ} 31^{\prime} \mathrm{W}\right.$, $903 \mathrm{~m}$ altitude). According to the classification of Köppen, the region's climate is tropical.

The experiment was installed in a randomized block design, with 8 treatments and three repetitions. The treatments consisted of eight sweet corn genotypes from $\mathrm{F} 3$ generation (L6P2, L6P15, L7P3, L8P7, L8P10, L8P12, L8P18, and L9P5), belonging to the Vegetable Germplasm Bank of UFU, Campus Monte Carmelo. This material was obtained from three successive selffecundations in ears collected in street market, initiated in 2016.

Seeds were sown in 200cell polystyrene trays for later transplantation, in order to ensure the establishment of the targeted population of 50 thousand plants/ha. The trays were filled with substrate and placed in a greenhouse. Transplanting to the field was performed when the seedlings reached $\mathrm{V}_{2}$ stage.

Seedlings transplantation to the field was at 4-cm soil depth, spaces between rows and between plants were 70 and $30 \mathrm{~cm}$, respectively. Each plot consisted of two rows $5.4 \mathrm{~m}$ in length, followed by $0.6 \mathrm{~m}$ of alley, with 32 plants per plot and useful area of $7.56 \mathrm{~m}^{2}$. Cropping practices and managements were performed throughout the cycle in accordance to the recommended for the sweet corn culture (Pereira Filho \& Teixeira, 2016).

In the $\mathrm{R}_{1}$ stage (female flowering), the plant stand (STD), number of prolific plants per plot (PP), number of fasciated plants per plot (FP), number of leaves per plant (LP), plant stalk diameter $(\mathrm{SD}, \mathrm{cm})$, plant height $(\mathrm{PH}$, $\mathrm{cm})$ and ear insertion height $(\mathrm{EH}, \mathrm{cm})$, were evaluated. After harvest in $\mathrm{R}_{4}$ stage (kernel dough stage), number of ears (NE), ear length (EL, cm), ear diameter $(\mathrm{ED}, \mathrm{cm})$, number of rows per ear (NRE), number of grains per row (NGR), grain yield (GY, $\mathrm{t} \mathrm{ha}^{-1}$ ) and industrial yield (IY, \%), relation between grain weight and ear weight (\%) were evaluated. In addition to the agronomic characteristics, the grain chemical evaluations regarding the content of soluble solids (SS), carbohydrates (CAR, \%), crude protein (CP, \%) and lipids (LIP, \%) were measured in accordance to the methodology of Instituto Adolfo Lutz (2007).

The presuppositions of analysis of variance (ANOVA) were calculated, and after acceptance, the data were submitted to ANOVA, with 0.05 significance level. After the detection of genetic variability for the evaluated traits and the estimation of the components of variance, the diagnosis of multicollinearity of the data was estimated from the matrix of phenotypic correlation by the condition number of the matrix $(\mathrm{CN})$ (Montgomery \& Peck, 1981). The results of the diagnosis were correlated in direct and indirect effects by trial analysis considering the chain collinearity (Cruz et al., 2012). For this reason, the constant $k$ was estimated at 5.26. Based on the trial analysis, the characteristics were selected for the composition of the indexes, considering only those with high direct effect on GY.

Finally, the base index (Williams, 1962), classic selection index (Smith, 1936; Hazel, 1943), desired gains index (Pesek \& Baker 1969) and genotypeideotype distance index (Cruz, 2006), being the genotype and the ideotype with maximum genotypic values, were observed. For the selection indexes studied, the value of economic weight adopted for GY was 2 and for the other characteristics was 1 in which all characteristics were evaluated in the crescent sense. When the indexes of desired gains were used, the desired gains equivalent to the genotypic standard deviation for each trait was established. In addition to the simultaneous selection of traits, analyzes of direct and indirect selection considering only one trait were performed. In this type of selection, the genotypes were selected based on the values of a single characteristic and calculated the gains in this same characteristic (direct selection) as well as in all other characteristics (indirect selection). Unlike the indexes, the direct and indirect selections were performed based on all evaluated characteristics, but one at a time.

According to each index, the genotypes were classified, and the three highest scores were selected. Considering the superior genotypes selected, the evaluation and comparison of selection indexes were made by calculating the selection gain for each characteristic. The selection gain was estimated by the expression $\mathrm{G}(\%)=$ $\left(D S \times h^{2}\right) \times 100$, being $\mathrm{G}(\%)=$ expected gain with the selection, $\mathrm{DS}=$ selection 
differential (the difference between the average of the selected population among the segregation populations from $\mathrm{F}_{3}$ generation and the average of the original segregation population of the $\mathrm{F}_{3}$ generation, and $h^{2}=$ coefficient of heritability in the broad sense. All statistical analyses were performed by the computational software Genes (Cruz, 2013).

\section{RESULTS AND DISCUSSION}

There were significant differences among the genotypes for fasciated plants (FP), number of leaves per plant (NLP), plant height $(\mathrm{PH})$, ear insertion height $(\mathrm{EH})$, number of ears (NE), ear length (EL), ear diameter (ED), number of rows per ear (NRE), number of grains per row (NGR), grain yield (GY) and industrial yield (IY) (Table 1). Identic to the other characteristics (STD, PP, SD, CAR, CP, LIP, SS), there was no difference among averages. The identification of genetic variability among the evaluated genotypes allows genetic gains from genotype selection (Cruz et al., 2012).

One of the most important parameters in plant breeding is the heritability, since it is directly related to the genetic gain. The heritability coefficients in the experiment ranged from $23.57 \%$ (SS) to $94.71 \%(\mathrm{PH})$, and GY showed heritability of $66.08 \%$, considered high in relation to what was found by Asghar \& Mehdi (2010) in sweet corn (38\%). Asghar \& Mehdi (2010) also observed NRE with a heritability of $84 \%$, a value close to that found in the present study (88.71\%). Cruz et al. (2012) reported that the use of secondary traits with high heritability and high correlation with the trait of interest can contribute to increasing the genetic gain.

The knowledge about direct and indirect effects of secondary traits on the main trait, obtained from the trial analysis, can optimize the selection indexes since traits of little relevance in the study can be early rejected (Cruz et al., 2012). In accordance to the trial analysis in the present study, $97 \%$ of the total variation of GY was explained by the characteristics studied (Table 2). The traits STD, NE, ED, and IY had a direct effect on the GY, once that showed direct effects greater than the residual effect (0.16). Sesay et al. (2017) also observed direct effects in the ear characteristics, as the number of rows, diameter, and length on the grain yield in hybrid maize populations. Teodoro et al. (2016) concluded that features not considered as main interest directly influence the productivity of grains in physic nut (Jatropha curcas). Therefore, in a process of simultaneous selection of traits, variables with a direct effect on GY can improve the gains on this characteristic. The other characteristics evaluated did not have a direct effect on grain yield, with values less than 0.16 .

The trial analysis indicated that the characteristics PP, FP, LP, SD, PH, EH, EL, NRE, CAR, CP, LIP, and SS had no direct effect on the GY. Thus, the criteria for direct and indirect selection

Table 1. Summary of the analysis of variance and estimation of genetic parameters for the traits of eight sweet corn genotypes. Monte Carmelo, UFU, 2018.

\begin{tabular}{|c|c|c|c|c|c|c|c|}
\hline \multirow{2}{*}{$\begin{array}{l}\text { Source of } \\
\text { Variation }\end{array}$} & \multirow{2}{*}{$D f$} & \multicolumn{6}{|c|}{ Mean square } \\
\hline & & STD & PP & FP & NLP & SD & PH \\
\hline Genotypes & 7 & 3.02 & 30.57 & $56.19 * *$ & $0.79 * *$ & 0.11 & $540.70 * *$ \\
\hline Blocks & 2 & 4.87 & 49.62 & 10.16 & 1.35 & 0.09 & 472.72 \\
\hline Residuals & 14 & 1.40 & 19.48 & 5.12 & 0.12 & 0.07 & 28.56 \\
\hline Average & & 32.75 & 12.50 & 5.16 & 10.47 & 2.33 & 117.32 \\
\hline CV $(\%)$ & & 3.61 & 35.31 & 43.79 & 3.28 & 11.85 & 4.55 \\
\hline CVg (\%) & & 2.24 & 15.38 & 79.85 & 4.53 & 4.38 & 11.13 \\
\hline $\mathrm{CVg} / \mathrm{CVe}(\%)$ & & 0.62 & 0.43 & 1.82 & 1.38 & 0.37 & 2.44 \\
\hline \multirow{2}{*}{$h^{2}(\%)$} & & 53.74 & 36.27 & 90.88 & 85.14 & 29.15 & 94.71 \\
\hline & & EH & NE & EL & ED & NRE & NGR \\
\hline Genotypes & 7 & $254.51 * *$ & $238.08^{* *}$ & $1.59 *$ & $0.34 * *$ & $1.58^{* *}$ & $31.39 *$ \\
\hline Blocks & 2 & 287.89 & 114.87 & 1.91 & 0.16 & 0.60 & 15.45 \\
\hline Residuals & 14 & 14.86 & 40.30 & 0.55 & 0.03 & 0.17 & 7.36 \\
\hline Average & & 57.41 & 49.12 & 18.05 & 4.53 & 14.64 & 24.02 \\
\hline CV (\%) & & 6.71 & 12.92 & 4.12 & 3.98 & 2.88 & 11.29 \\
\hline CVg (\%) & & 15.56 & 16.52 & 3.26 & 7.16 & 4.67 & 11.78 \\
\hline $\mathrm{CVg} / \mathrm{CVe}(\%)$ & & 2.31 & 1.27 & 0.79 & 1.79 & 1.61 & 1.04 \\
\hline \multirow[t]{2}{*}{$h^{2}(\%)$} & & 94.16 & 83.07 & 65.28 & 90.63 & 88.71 & 76.54 \\
\hline & & GY & IY & CAR & $\mathbf{C P}$ & LIP & SS \\
\hline Genotypes & 7 & $7.30^{*}$ & $183.55^{* *}$ & 1.29 & 0.78 & 0.38 & 1.43 \\
\hline Blocks & 2 & 16.68 & 52.97 & 0.07 & 0.37 & 0.10 & 3.13 \\
\hline Residuals & 14 & 2.47 & 13.50 & 0.70 & 0.31 & 0.23 & 1.09 \\
\hline Average & & 7.51 & 45.18 & 19.92 & 6.32 & 2.63 & 11.47 \\
\hline CV (\%) & & 20.94 & 8.13 & 4.22 & 8.90 & 18.17 & 9.13 \\
\hline CVg (\%) & & 16.87 & 16.66 & 2.21 & 6.20 & 8.74 & 2.92 \\
\hline $\mathrm{CVg} / \mathrm{CVe}(\%)$ & & 0.80 & 2.04 & 0.52 & 0.69 & 0.48 & 0.32 \\
\hline$h^{2}(\%)$ & & 66.08 & 92.64 & 45.04 & 59.28 & 40.99 & 23.57 \\
\hline
\end{tabular}

$* *, *=$ significant at 1 and $5 \%$ probability by the $\mathrm{F}$ test, respectively; $\mathrm{Df}=$ degree of freedom; $\mathrm{CV}, \mathrm{CVg}$ and $\mathrm{CVe}=$ coefficient of variation, coefficient of genetic variation and coefficient of experimental variation, respectively; $h^{2}=$ heritability in the broad sense; $\mathrm{STD}=$ plant stand; $\mathrm{PP}=$ prolific plants; $\mathrm{FP}=$ fasciated plants; $\mathrm{NLP}=$ number of leaves per plant; $\mathrm{SD}=$ stalk diameter $(\mathrm{cm}) ; \mathrm{PH}$ and $\mathrm{EH}=$ plant and ear height $(\mathrm{cm}) ; \mathrm{NE}=$ number of ears; $\mathrm{EL}=$ ear length $(\mathrm{cm}) ; \mathrm{ED}=$ ear diameter $(\mathrm{cm}) ; \mathrm{NRE}=$ number of rows per ear; $\mathrm{NGR}=$ number of grains per row; $\mathrm{GY}=$ grain yield $\left(\mathrm{t} \mathrm{ha}^{-1}\right) ; \mathrm{IY}=$ industrial yield $(\%)$; CAR, CP and $\mathrm{LIP}=$ amount of carbohydrate, crude protein and lipids in grains $(\%)$; $\mathrm{SS}=$ grain soluble solids $\left({ }^{\circ} \mathrm{Brix}\right)$. 
and selection indexes were calculated based on the following characteristics: STD, NE, ED, NGR, GY, and IY.

According to Falconer (1987), higher gains offered by indirect selection are expected if the heritability of secondary characteristics is greater than that of the principal characteristic considered and these characteristics (principal and secondary) are highly correlated. However, in this work it does not occur, because all estimated direct gains were superior to indirect gains (Table 3).

The direct selection based on GY provided gains (11.65\%) for this characteristic and positive gain for the other characteristics. However, the selection based on a single characteristic can occasionally cause unwanted changes in several other traits not considered (Cruz et al., 2012). Carvalho et al. (2017) reported a reduction in important traits, such as mass and diameter of roots when aiming the improvement of carrot genotypes by selections supported on only the characteristic coloration of roots.

The base index was the one that generated the greatest total selection gain (sum of gains in all the characteristics evaluated), with a value of $38.69 \%$ (Table 4), and also showed a greater gain for IY $(13.53 \%)$ and NGR $(8.71 \%)$ among all the indexes studied. The improvement of sweet corn genotypes with great IY and great NGR, are important characteristics for the yield in the ear industrial processing (Luz et al., 2014). In addition, the base index was the only one that showed no estimates for undesirable gain. Although this index presented an adequate total gain, it does not show the greatest gain in grain yield (GY). Vivas et al. (2013) emphasized the base index as the most suitable for the selection of superior genotypes of papaya.

The highest estimate of gain in GY $(9.76 \%)$ was observed with the classic indexes. In the same way, in another study with sweet corn, this was also the one which provided higher gain in GY (Asghar \& Mehdi, 2010). On the other

Table 2. Direct effects (diagonal in bold) and indirect effects of the variables considered primary on the main variable grain yield (GY), evaluated in eight sweet corn genotypes. Monte Carmelo, UFU, 2018.

\begin{tabular}{|c|c|c|c|c|c|c|c|c|c|c|c|c|c|c|c|c|c|}
\hline IE & STD & PP & FP & NLP & SD & PH & EH & NE & EL & ED & NRE & NGR & IY & CAR & $\mathrm{CP}$ & LIP & SS \\
\hline STD & 0.28 & 0.08 & 0.18 & -0.01 & 0.15 & -0.01 & -0.03 & 0.20 & 0.03 & 0.01 & 0.03 & 0.12 & 0.03 & -0.07 & 0.02 & 0.11 & 0.11 \\
\hline PP & 0.01 & 0.03 & 0.03 & 0.02 & 0.02 & 0.00 & 0.01 & 0.03 & 0.00 & -0.01 & 0.00 & 0.02 & 0.00 & -0.01 & 0.01 & 0.00 & -0.01 \\
\hline FP & 0.10 & 0.13 & 0.15 & 0.06 & 0.10 & 0.05 & 0.05 & 0.14 & 0.06 & -0.05 & -0.03 & 0.08 & 0.00 & -0.08 & 0.08 & 0.02 & -0.01 \\
\hline NLP & 0.00 & 0.03 & 0.02 & 0.06 & 0.00 & 0.04 & 0.02 & 0.03 & 0.02 & -0.01 & 0.01 & 0.00 & -0.02 & -0.01 & 0.04 & -0.03 & 0.02 \\
\hline SD & -0.04 & -0.05 & -0.05 & 0.00 & -0.07 & 0.02 & 0.01 & -0.05 & 0.02 & 0.01 & 0.01 & -0.05 & -0.01 & 0.02 & 0.00 & -0.03 & 0.00 \\
\hline PH & 0.00 & 0.00 & -0.01 & -0.01 & 0.00 & -0.02 & -0.01 & 0.00 & -0.02 & 0.01 & 0.01 & 0.01 & 0.01 & 0.01 & -0.01 & 0.00 & -0.01 \\
\hline EH & 0.01 & -0.02 & -0.03 & -0.03 & 0.02 & -0.07 & -0.08 & -0.02 & -0.07 & 0.06 & 0.04 & 0.03 & 0.04 & 0.20 & -0.05 & 0.00 & 0.01 \\
\hline NE & 0.12 & 0.14 & 0.16 & 0.08 & 0.11 & 0.04 & 0.04 & 0.17 & 0.05 & -0.04 & 0.01 & 0.09 & 0.00 & -0.08 & 0.09 & 0.00 & 0.02 \\
\hline EL & 0.02 & 0.02 & 0.06 & 0.06 & -0.03 & 0.14 & 0.14 & 0.04 & 0.15 & -0.07 & -0.08 & -0.06 & -0.08 & -0.10 & 0.00 & 0.02 & 0.02 \\
\hline ED & 0.01 & -0.10 & -0.14 & -0.04 & -0.07 & -0.24 & -0.30 & -0.11 & -0.19 & 0.41 & 0.09 & 0.15 & 0.27 & 0.25 & 0.16 & -0.12 & 0.02 \\
\hline NRE & 0.00 & 0.00 & 0.01 & 0.00 & 0.01 & 0.01 & 0.02 & 0.00 & 0.02 & -0.01 & -0.04 & 0.00 & 0.00 & -0.01 & 0.00 & 0.02 & -0.01 \\
\hline NGR & 0.08 & 0.13 & 0.10 & 0.01 & 0.13 & -0.10 & -0.07 & 0.10 & -0.07 & 0.07 & -0.01 & 0.19 & 0.13 & 0.06 & 0.05 & -0.03 & -0.06 \\
\hline IY & 0.03 & 0.04 & -0.01 & -0.12 & 0.02 & -0.22 & -0.14 & -0.01 & -0.15 & 0.19 & 0.02 & 0.20 & 0.29 & 0.20 & 0.14 & -0.09 & -0.18 \\
\hline CAR & -0.01 & -0.01 & -0.02 & -0.01 & -0.02 & -0.03 & -0.02 & -0.02 & -0.03 & 0.03 & 0.01 & 0.01 & 0.03 & 0.05 & 0.03 & -0.03 & -0.02 \\
\hline $\mathrm{CP}$ & 0.01 & 0.05 & 0.06 & 0.08 & 0.00 & 0.10 & 0.08 & 0.06 & 0.09 & -0.05 & 0.00 & -0.03 & -0.06 & -0.09 & 0.12 & -0.01 & 0.02 \\
\hline LIP & -0.02 & 0.01 & -0.01 & 0.03 & -0.03 & 0.00 & 0.00 & 0.00 & -0.01 & 0.02 & 0.03 & 0.01 & 0.02 & 0.04 & 0.01 & -0.06 & -0.02 \\
\hline SS & 0.02 & -0.02 & 0.00 & 0.02 & 0.00 & 0.02 & -0.01 & 0.01 & 0.01 & 0.00 & 0.02 & -0.02 & -0.03 & -0.02 & 0.01 & 0.02 & 0.05 \\
\hline Total & 0.63 & 0.45 & 0.52 & 0.20 & 0.34 & -0.03 & -0.28 & 0.58 & -0.07 & 0.60 & 0.10 & 0.77 & 0.63 & 0.20 & 0.04 & -0.22 & -0.04 \\
\hline
\end{tabular}

Residual effect $=0.16$; coefficient of determination $=0.97$; constant $\mathrm{k}=5.26 ; \mathrm{IE}=$ indirect effect $\mathrm{STD}=$ plant $\mathrm{stand} ; \mathrm{PP}=$ prolific plants; $\mathrm{FP}=$ fasciated plants; $\mathrm{NLP}=$ number of leaves per plant; $\mathrm{SD}=$ stalk diameter $(\mathrm{cm}) ; \mathrm{PH}$ and $\mathrm{EH}=$ plant and ear height $(\mathrm{cm}) ; \mathrm{NE}=$ number of ears; $\mathrm{EL}=$ ear length $(\mathrm{cm}) ; \mathrm{ED}=$ ear diameter $(\mathrm{cm}) ; \mathrm{NRE}=$ number of rows per ear, $\mathrm{NGR}=$ number of grains per row; IY= industrial yield $(\%)$; $\mathrm{CAR}, \mathrm{CP}$ and $\mathrm{LIP}=$ amount of carbohydrate, crude protein and lipids in grains $(\%)$; $\mathrm{SS}=$ grain soluble solids $\left({ }^{\circ} \mathrm{Brix}\right)$. 
Table 3. Estimates of selection gains by direct selection (diagonal in bold) and indirect (in rows), for the traits of eight sweet corn genotypes. Monte Carmelo, UFU, 2018.

\begin{tabular}{llrrrrrr}
\hline \multirow{2}{*}{$\begin{array}{l}\text { Traits used in the } \\
\text { direct selection }\end{array}$} & \multirow{2}{*}{ Selected genotypes } & \multicolumn{6}{c}{ Selection gains direct and indirect (\%) } \\
\cline { 3 - 7 } & STD & \multicolumn{1}{c}{ NE } & ED & NGR & GY & IY \\
\hline STD & L6P15, L8P12 and L8P7 & $\mathbf{1 . 5 0}$ & 12.00 & 1.09 & 3.44 & 9.90 & -2.26 \\
NE & L6P15, L8P10 and L8P12 & 1.32 & $\mathbf{1 6 . 7 0}$ & -1.62 & 5.67 & 9.76 & 1.77 \\
ED & L6P2, L7P3 and L8P7 & 0.05 & -10.73 & $\mathbf{5 . 5 6}$ & 1.03 & 2.54 & 9.37 \\
NGR & L6P15, L6P2 and L7P3 & 0.19 & 1.10 & 2.52 & $\mathbf{9 . 6 0}$ & 5.82 & 10.74 \\
GY & L6P15, L7P3 and L8P12 & 0.77 & 11.06 & 1.89 & 8.86 & $\mathbf{1 1 . 6 5}$ & 4.42 \\
IY & L6P15, L7P3 and L8P10 & 0.41 & 7.49 & 0.03 & 8.71 & 8.52 & $\mathbf{1 3 . 5 3}$ \\
\hline
\end{tabular}

$\mathrm{STD}=$ plant stand; $\mathrm{NE}=$ number of ears; $\mathrm{ED}=$ ear diameter $(\mathrm{cm}) ; \mathrm{NGR}=$ number of grains per row; $\mathrm{GY}=$ grain yield $\left(\mathrm{t}\right.$ ha $\left.{ }^{-1}\right) ; \mathrm{IY}=\mathrm{industrial}$ yield $(\%)$.

Table 4. Estimates of selection genetic gain with the use of selection indexes for the traits of eight sweet corn genotypes. Monte Carmelo, UFU, 2018.

\begin{tabular}{lcccc}
\hline \multirow{2}{*}{ Traits } & \multicolumn{4}{c}{ Selection genetic gain (\%) } \\
\cline { 2 - 5 } & Base index & Classic index & $\begin{array}{c}\text { Desired gains } \\
\text { index }\end{array}$ & $\begin{array}{c}\text { Genotype-ideotype } \\
\text { distance index }\end{array}$ \\
\hline STD & 0.41 & 1.32 & 0.96 & 0.96 \\
NE & 7.49 & 16.70 & 6.74 & 4.86 \\
ED & 0.03 & -1.62 & -0.99 & 1.43 \\
NGR & 8.71 & 5.67 & 6.41 & -2.90 \\
GY & 8.52 & 9.76 & 3.92 & 6.47 \\
IY & 13.53 & 1.77 & 8.08 & 0.40 \\
\hline Total & 38.69 & 33.60 & 25.12 & 11.22 \\
\hline Selected & L6P15, L7P3 & L6P15, L8P10 & L6P15, L6P2 & L8P10, L8P12 and \\
genotypes & and L8P10 & and L8P12 & and L8P10 & L8P7 \\
\hline STD- pl
\end{tabular}

$\mathrm{STD}=$ plant stand; $\mathrm{NE}=$ number of ears; $\mathrm{ED}=$ ear diameter $(\mathrm{cm}) ; \mathrm{NGR}=$ number of grains per row; $\mathrm{GY}=$ grain yield $\left(\mathrm{t} \mathrm{ha}^{-1}\right) ; \mathrm{IY}=$ industrial yield $(\%)$.

hand, Freitas et al. (2013) found for GY in popcorn no desirable gains by classic indexes. The estimates of gains by the same indexes do not always show similar results, because the variables that compose the indexes, the type and number of genotypes available, the genotype by environment interaction, the values of the economic weights and the accuracy of the matrices of variances and covariances interfere in the indexes (Cruz et al., 2012).

The indexes used in this study, except the base index, showed no positive desirable gains for all evaluated traits. Similarly, Oliveira et al. (2008) found that the classic indexes and desired gains also provided negative gains of some traits in progenies of yellow passion fruit. However, Santos et al. (2007) used different economic weights and found that the classic indexes allowed the achievement of positive gains for the main characteristics in popcorn, while the indexes of desired gains provided considerable gains only when using economic weight equal to the genetic standard deviation.

The selection indexes are efficient, besides presenting favorable genetic gains in all characteristics, especially those of primary interest, although, the gains must be well distributed among all traits (Bhering et al., 2012). Although the indexes of desired gains and genotype-ideotype distance have presented lower total gains than the base index, they obtained balanced gains between the evaluated characteristics (Figure 1). There are studies that reported the contents of genotypeideotype distance as the more suitable strategy of selection for the simultaneous breeding of characteristics, by providing a balanced distribution of expected gains for all evaluated traits (Bhering et al., 2012; Carvalho et al., 2017; Oliveira et al., 2008). Moreover, in the present study, genotype-ideotype distance index presented satisfactory gain linear diameter; the other indexes provided low gains (base index) or negative (classic and desired gains) for this characteristic.

The classic index provided higher gain for number of ears, therefore this index selected more prolific genotypes. The prolificacy has not been a characteristic prioritized by breeding programs of corn (Elias et al., 2010). In addition, on the sweet corn crop, the priority is the quality of the first ear due to industrial processing (Assunção et al. 2010). For the characteristic NGR, only the genotype-ideotype distance index gave negative gain $(-2,90 \%)$ (Table 4$)$.

There were no coincidences in relation to selected genotypes among the studied indexes and also by direct selection based on GY (Tables 3 and 4). However, the base index and the direct selection based on IY selected the same genotypes (L6P15, L7P3 and L8P10). Furthermore, the genotypes L8P18 and L9P5 were the only ones not selected by any of the indexes.

Another important factor in the simultaneous selection of characteristics is the determination of the economic weights of the main and secondary characteristics; however, in this study, the variations in weights for the same indexes were not evaluated (Cruz et al., 2012). Generally, the values established for the weights in the indexes may influence the expected gains. Bizari 


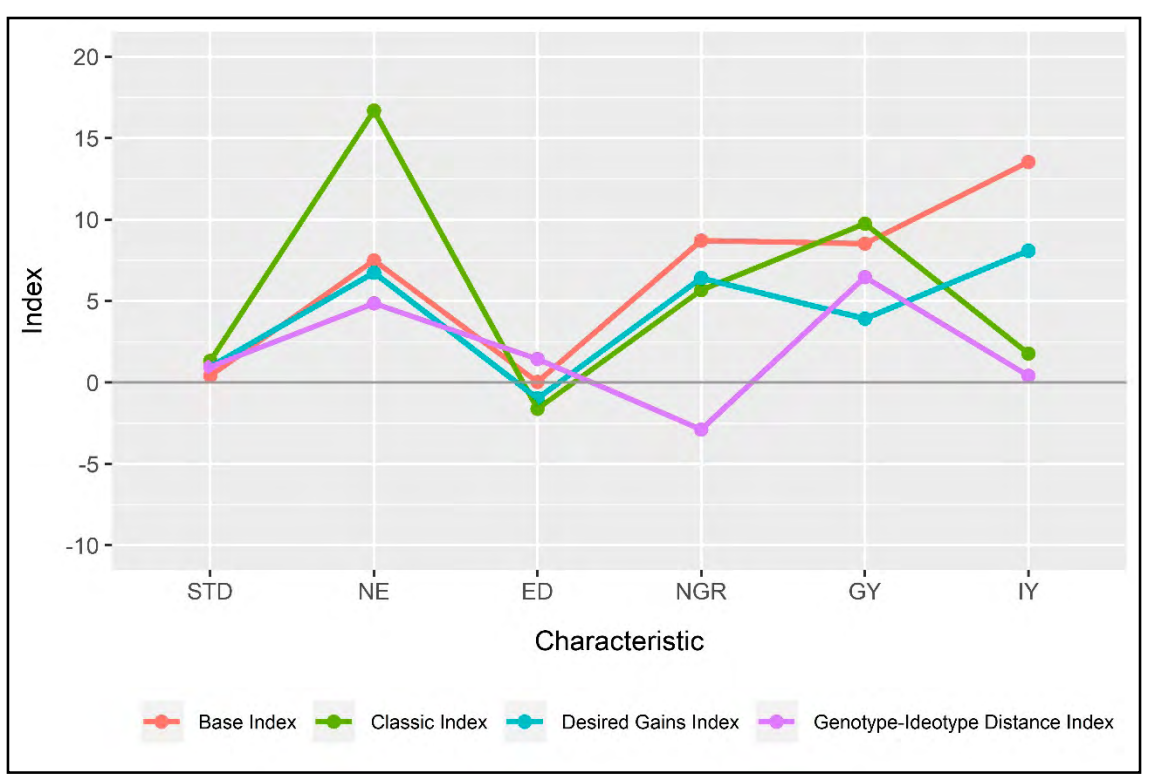

Figure 1. Distribution of estimates of genetic gain in line graph by base index, classic index, desired gains and genotype-ideotype distance for the traits of eight sweet corn genotypes. Monte Carmelo, UFU, 2018.

et al. (2017) observed that for certain indexes, the variation in economic weights influenced the genetic gains in segregating soybean populations. On the other hand, estimates of total gain were similar among tomato genotypes, regardless of the economic weight used (Nick et al., 2013). There are, however, more recent indexes that do not take into account the economic weights, such as the analysis of factors associated with the main components, PPG-ESIM and FAI-BLUP (DoVale et al., 2011; CerónRojas et al., 2016; Rocha et al., 2018).

The superiority of the selection indexes in relation to other selection methods and from one index to the other is variable (Oliveira et al., 2008). This variation depends mainly on the accuracy in the estimation of the variances and covariances genetic and phenotypic characteristics, the number of genotypes evaluated and selected, and, if used, the accuracy in the determination of economic weights or desired gains for each characteristic (Asghar \& Medhi, 2010; Cruz et al., 2012).

In this study, the base index was the most efficient in the simultaneous selection of characteristics in sweet corn by providing the largest selection gain total, desirable gains positive in all characteristics, uniform distribution of gains between the characteristics evaluated and gain satisfactory in grain yield. The base index allows great selection gain simultaneously in many important characteristics of sweet corn, which becomes the selection process more efficient.

\section{ACKNOWLEDGMENTS}

This research was supported by the National Council for Scientific and Technological Development (CNPq), Coordination for the Improvement of Higher Education Personnel (CAPES) and Federal University of Uberlândia (UFU).

\section{REFERENCES}

ANDRADE, ACB; SILVA, AJ; FERRAUDO, AS; UNÊDA-TREVISOLI, SH; MAURO, AS. 2016. Strategies for selecting soybean genotypes using mixed models and multivariate approach. African Journal of Agricutural Research 11: 23-31.

ASGHAR, MJ; MEHDI, SS. 2010. Selection indices for yield and quality traits in sweet corn. Pakitan Journal of Botany 42: 775-789.

ASSUNÇÃO, A; BRASIL, EM; OLIVEIRA, JP; REIS, AJS; PERREIRA, AF; BUENO, LG; RAMOS, MR. 2010. Heterosis performance in industrial and yield components of sweet corn.
Crop Breeding and Applied Biotechnology. 10: $183-190$.

BHERING, LL; LAVIOLA, BG; SALGADO, CC; SANCHEZ, CFB; ROSADO, TB; ALVES, AA. 2012. Genetic gains in physic nut using selection indexes. Pesquisa Agropecuária Brasileira 47: 402-408.

BIZARI, EH; VAL, BHP; PEREIRA, EM; DI MAURO, AO; UNÊDA-TREVISOLI, SH. 2017. Selection indices for agronomic traits in segregating populations of soybean. Revista Ciência Agronômica 48: 110-117.

CARVALHO, ADF; NOGUEIRA, MTM; SILVA, GO; LUZ, JMQ; MACIEL, GM; RABELO PG. 2017. Seleção de genótipos de cenoura para caracteres fenotípicos de raiz. Horticultura Brasileira 35: 97-102.

CERÓN-ROJAS, JJ; CROSSA, J; TOLEDO, FH; SAHAGÚN-CASTELLANOS, J. 2016. A predetermined proportional gains eigenselection index method. Crop Science 56: 2436-3447.

CRUZ, CD. 2013. GENES - a software package for analysis in experimental statistics and quantitative genetics. Acta Scientiarum 35: 271-276.

CRUZ, CD; REGAZZI, AJ; CARNEIRO, PCS. 2012. Modelos biométricos aplicados ao melhoramento genético - Volume 1. Viçosa: Editora UFV. 514p.

CRUZ, CD. 2006. Programa GENES: biometria. Viçosa: Editora UFV. 382 p.

DODSON-SWENSON, HG; TRACY, WF. 2015. Endosperm carbohydrate composition and kernel characteristics of shrunken2intermediate (sh2-i/sh2-i Su1/Su1) and shrunken2-intermediate-sugary1-reference (sh2-i/sh2-i su1-r/su1-r) in sweet corn. Crop Science 55: 2647-2656.

DOVALE, JC; FRITSCHE-NETO, R; SILVA, PSL. 2011. Índice de seleção para cultivares de milho com dupla aptidão: minimilho e milho verde. Bragantia 70: 781-787.

ELIAS, HT; VOGT, GA; VIEIRA, LC; PINHO, RGV; NASPOLINI, V; COVER, C. 2010. Melhoramento genético do milho. In: FILHO, JAW; ELIAS, HT (eds). A cultura do milho em Santa Catarina. Florianópolis: Epagri. p.414-480.

FALCONER, DS. 1987. Introdução à genética quantitativa. Viçosa: Editora UFV. 279p.

FREITAS, ILJ; AMARAL JUNIOR, AT; VIANA, AP; PENA, GF; CABRAL, OS; VITTORAZZI, C; SILVA, TRC. 2013. Ganho genético avaliado com índices de seleção com REML/Blup em milho-pipoca. Pesquisa Agropecuária Brasileira 48: 1464-1471.

HAZEL, HN. 1943. The genetics basis for constructing selection indexes. Genetics 28: 476-490.

INSTITUTO ADOLFO LUTZ. 2007. Métodos fisico-químicos para análise de alimentos. São Paulo: Valera. 1017p.

JAHUFER, MZZ; CASLER, MD. 2015. Application of the Smith-Hazel selection index for improving biomass yield and quality of switch grass. Crop Science 55: 1212-1222.

LEITE, WS; UNÊDA-TREVISOLI, SH; SILVA, 
FM; SILVA, AJ; DI MAURO, AO. 2018. Identification of superior genotypes and soybean traits by multivariate analysis and selection index. Revista Ciência Agronômica 49: 491-500.

LUZ, JMQ; CAMILO, JS; BARBIERI, VHB; RANGEL, RM; OLIVEIRA, RC. 2014. Produtividade de genótipos de milho doce e milho verde em função de intervalos de colheita. Horticultura Brasileira 32: 163-167.

MAPA - MINISTÉRIO DA AGRICULTURA, PECUÁRIA E ABASTECIMENTO. 2019. Registro Nacional de Cultivares. Available at http://sistemas.agricultura.gov.br/snpc/ cultivarweb/cultivares_registradas.php. Accessed March 26, 2019.

MISSANJO, E; MATSUMURA, J. 2017. Multiple traits selection index for simultaneous improvement of wood properties and growth traits in Pinus kesiya ex Gordon in Malawi. Forest 8: 1-7.

MONTGOMERY, DC; PECK, EA. 1981. Introduction to linear regression analysis. New York: John Wiley. 504p.

NEVES, LG; BRUCKNER, CH; CRUZ, CD; VIANA, AP; BARELLI, MAA. 2011. Predição de ganhos, com diferentes índices de seleção, para características de frutos do maracujazeiro-amarelo. Revista Brasileira de
Fruticultura 33: 1322-1330.

NICK, C; LAURINDO, BS; ALMEIDA, VS; FREITAS, RD; AGUILERA, JG; SILVA, ECF; CRUZ, CD; SILVA, DJH. 2013. Seleção simultânea para qualidade do fruto e resistência à requeima em progênies de tomateiro. Pesquisa Agropecuária Brasileira 48: 59-65.

OLIVEIRA, EJ; SANTOS, VS; LIMA, DS; MACHADO, MD; LUCENA, RS; MOTTA, TBN; CASTELLEN, MS. 2008. Seleção de progênies de maracujazeiro-amarelo com base em índices multivariados. Pesquisa Agropecuária Brasileira 43: 1543-1549.

PEREIRA FILHO, IA; TEIXEIRA, FF. 2016. $O$ cultivo do milho-doce. Brasília: Embrapa. 298p.

PERFEITO, DGA; LOPES, MCM; SALOMÃO, LC; SOUZA, MLC; BENETT, CGS; LIMA, BP. 2017. Caracterização pós colheita de milho doce submetido ao parcelamento de fertirrigação nitrogenada. Brazilian Journal of Food Technology 20: 2-7.

PESEK, J; BAKER, RJ. 1969. Desired improvement in relation to selected indices. Canadian Journal of Plant Sciences 49: 803-804.

ROCHA, JRASC; MACHADO, JC; CARNEIRO, PCS. 2018. Multitrait index bases on fator analysis and ideotype-design: proposal and application on elephant grass breeding for bioenergy. Global Change Biology Bioenergy 10: 52-60.

SANTOS, FS; AMARAL JÚNIOR, AT; FREITAS JÚNIOR, SP; RANGEL, RM; PEREIRA, MG. 2007. Predição de ganhos genéticos por índices de seleção na população de milho-pipoca UNB-2U sob seleção recorrente. Bragantia 66: 389-396.

SESAY, S; OJO, DK; ARIYO, OJ; MESEKA, S; FAYEUN, LS; OMIKUNLE, AO; OYETUNDE, AO. 2017. Correlation and path coefficient analysis of top-cross and threeway cross hybrid maize populations. African Journal of Agricultural Research 12: 780-789.

SMITH, HF. 1936. A discriminant function for plant selection. Annals of Eugenics 7: 240-250.

TEODORO, PE; COSTA, RD; ROCHA, RB; LAVIOLA BG. Contribution of agronomic traits for grain yield in physic nut. Bragantia 75: 51-56.

VIVAS, M; SILVEIRA, SF; VIVAS, JMS; PEREIRA, MG. 2013. Predição de ganhos genéticos e seleção de progênies de mamoeiro para resistência à pinta-preta. Tropical Plant Pathology 38: 142-178.

WILLIAMS, JS. 1962. The evolution of a selection index. Biometrics 18: 375-393. 